\title{
Bloated balance sheets and stock returns: Asymmetries between profit and loss firms
}

\author{
Georgios A. Papanastasopoulos* \\ Department of Business Administration, University of Piraeus, Piraeus, Greece
}

Received: 11 July 2018

Revised: 8 February 2019

Accepted: 9 February 2019

\begin{abstract}
We study return predictability attributable to bloated balance sheets in European capital markets and find that the NOA anomaly is more severe across loss firms and is significantly attenuated across profit firms. A hedge trading strategy on NOA for loss firms generate large raw and abnormal returns that are almost three times higher than the respective returns for profit firms. Our evidence is more likely to be consistent with the hypothesis that low NOA firms may have superior returns relative to high NOA firms due to investors' inability to make full use of information reported in financial statements.
\end{abstract}

Keywords: net operating assets; stock returns; profits; losses; Europe JEL Classification Codes: G1, M4

\section{Introduction}

The level of net operating assets represents the cumulation over time of the deviation between accounting value added (net operating income) and cash value added (free cash flow). Thus, net operating assets are a cumulative measure of total accruals - a measure of balance sheet bloat. Hirshleifer et al. (2004) show that the level of net operating assets scaled by lagged total assets (NOA, hereafter) is a strong negative predictor of stock returns in the cross section of U.S. stock returns. This finding is referred in the literature as the NOA "anomaly", whereby firms with low NOA outperform firms with high NOA. Recently, Papanastasopoulos and Thomakos (2017) provide evidence that the NOA anomaly occurs outside the U.S. and more specifically in European capital markets.

While there is extensive evidence on the occurrence of the NOA anomaly, consensus on its interpretation has been elusive. According to the mispricing explanation, originally proposed

\footnotetext{
*E-mail: papanast@unipi.gr.
}

Citation: Papanastasopoulos, G. A. (2019) Bloated balance sheets and stock returns: Asymmetries between profit and loss firms, Economics and Business Letters, 8(1), 53-61.

DOI: 10.17811/ebl.8.1.2019.53-61 
by Hirshleifer et al. (2004), the NOA anomaly is driven from investors' failure to incorporate fully the information contained in financial reports owing to functional fixation on earnings or limited attention. In particular, a high level of NOA indicates that current earnings performance is unlikely to be sustained in the future, causing naïve investors that do not fully discount for this lack of sustainability to make systematic errors that affect market prices; firms with high NOA are overvalued relative to those with low NOA. According to the risk explanation, originally argued by $\mathrm{Wu}$ et al. (2010), the NOA anomaly arises as managers optimally adjust investment expenditures upwards (i.e., leading to a higher level of NOA) in a rational response to the reduction in the cost of capital. As such, whether the NOA anomaly represents rational risk premium or market inefficiency is still under debate (Hirshleifer et al. 2012).

In this paper, we provide additional insights on the NOA anomaly by investigating, whether it occurs across both profit and loss firms in European capital markets. We are motivated by a desire to enhance our understanding on what drives a prominent empirical regularity like the NOA anomaly in a global setting. We focus on return predictability attributable to NOA, conditional on earnings signs, and particularly losses due to at least three reasons.

First, it is well documented that investors react differently to loss firms as compared to profit firms (e.g., Patatoukas, 2016). At the same time, a separate examination of loss firms is warranted given that they constitute a significant portion of the economy and their percentage has increased significantly over the past several decades.

Second, losses are less sustainable than profits either due to an abandonment option, whereby firms with losses are more likely to curtail operations (e.g., Hayn 1995) or due to timely loss recognition stemming from conditional conservatism in financial reporting (e.g., Basu 1997). In this line, Schleicher et al. (2007) claim that for loss making firms, current income is not a good guide about the longer-term earnings performance of the firm. Thus, the sustainability effect associated with NOA is expected to be stronger across loss years relative to profit years.

Third, the profit versus loss classification of firms represents a simple, yet powerful, earnings heuristic (due to less than perfect rationality), which may be used as a reference point for investors with limited capacity to simplify problems of choice and of processing of vast amounts of available accounting information (see Pinnuck and Shekhar, 2013). The partial use of information may lead, in turn, to cognitive biases. Behavioral biases are expected to be larger around loss announcements, when uncertainty is greater.

The unique setting of loss firms, allow us to examine whether the NOA anomaly represents a systematic mispricing pattern. Such a possibility suggests asymmetries on return predictability associated with NOA, conditional on the sign of accounting earnings. In particular, the NOA anomaly is expected to be more pronounced across loss firms relative to profit firms.

Given the ongoing debate among academics about the determinants of stock market anomalies attributable to accounting figures, as well as practical implications for practitioners who implement strategies to take advantage of anomalous behavior (e.g., Grobys, 2014), we examine the international NOA anomaly separately for firms with positive and negative accounting earnings. In doing so, we focus on a sample of developed European equity markets that mirrors the well-known European stock market benchmark from Morgan Stanley Capital International (MSCI).

Like in the United States, we find that firms with high NOA underperform firms with low NOA. A hedge trading strategy based on a long position on an equally-weighted portfolio of low-NOA stocks and a short position on an equally-weighted portfolio of high-NOA stocks earns an average raw return of $8.98 \%$ per annum. The respective hedge return across loss firms is rising to $16.94 \%$, while across profit firms it is declining to $6.53 \%$. Similar evidence we find, 
when we consider excess returns by adjusting for size and book to market ratio. ${ }^{1}$

The remainder of this paper is organized as follows. In the next section, we describe the data, while in Section 3 we present the empirical framework and findings. Finally, in section 4 we offer our concluding remarks.

\section{Data}

We examine the NOA anomaly in an integrated European equity market that consists of firms from 16 developed markets: Austria, Belgium, Denmark, Finland, France, Germany, Greece, Ireland, Italy, Netherlands, Norway, Portugal, Spain, Sweden, Switzerland, and the United Kingdom. Data are obtained from Datastream and Worldscope. The sample period spans 25 years from 1989 through 2013. We perform all the data screenings for basic coding errors via the methods suggested by Ince and Porter (2006). To be included in the analysis, all firms are required to have sufficient financial data to compute NOA, current and one-year ahead profitability, size, book to market ratio and one-year ahead raw and abnormal returns. ${ }^{2}$ Companies from the financial sector are excluded, since the discrimination between operating and financing activities is not clear for these companies and as result the definition of NOA is not meaningful for them. This yields a final sample of 72,180 annual firm-year observations.

\section{Empirical findings}

In Table 1 we report descriptive statistics. The empirical distributions of NOA are similar to those reported in prior studies research (e.g., Hirshleifer et al. 2004; Papanastasopoulos and Thomakos, 2017). The annual raw and abnormal returns are significantly negative correlated with NOA. To separate profit from loss firms, we rely on the sign of current earnings. Accordingly, profit (loss) firms are those that report positive (negative) accounting earnings at financial year-end. The sample consists of about $75 \%$ of profit years and about $25 \%$ of loss years. The reported statistics about NOA across loss firms are on average much higher than the respective counterparts across profit firms.

Table 2 reports mean values of NOA, one-year ahead profitability growth, one-year ahead raw and abnormal returns to NOA portfolios. In each year, stocks are sorted into five equalweighted portfolios according to the magnitude of NOA. The portfolios are held for one year then re-formed. We also report, the average annual difference in characteristics and returns between the bottom and top NOA portfolios. The spread in annual returns constitutes the hedge return on a trading strategy taking a long (short) position on the lowest (highest) NOA portfolio.

\footnotetext{
${ }^{1}$ Chan et al. (2009) argue that returns adjusted by size and book-to-market deliver more plausible levels of performance and lower errors at tracking the returns of actively-managed portfolios. Fama and French (2008) claim that size and book-to-market adjusted returns are almost similar to factor alphas from the Fama and French (1993) three-factor model. We avoid using the Fama and French (2015) five-factor model that adds profitability and investment factors to the Fama and French (1993) three-factor model due to its failure to capture fully the low average returns of small stocks that invest aggressively, despite low profitability. We need to stress here, that Fama and French (2017) provide empirical evidence consistent with the above mentioned drawback of the Fama and French (2015) five-factor model in an international study that includes Europe, which constitutes the region under investigation in our paper.

${ }^{2}$ We use annualized monthly returns. In particular, once we get monthly returns, we measure one-year ahead annual raw stock returns using compounded 12 monthly buy-and-hold returns. The return cumulation period starts 6 months after financial year-end. To measure abnormal returns, we use the characteristic-based benchmark approach and adjust for size and book-to-market effects.
} 
Table 1. Summary statistics on net operating assets. This table provides summary statistics on net operating assets across the whole sample and subsamples of profit and loss firms. Panel A reports univariate statistics (mean, standard deviation, 25th percentile, median, 75th percentile) on net operating assets. Panel B reports pairwise correlations of net operating assets with profitability growth and with future raw and abnormal returns. $* * * * *$ and $*$ denote statistical significance of pairwise correlations at $1 \%$, $5 \%$, and $10 \%$ level, respectively, two-tailed.

\begin{tabular}{|c|c|c|c|c|c|c|}
\hline \multicolumn{7}{|c|}{ Panel A: Univariate statistics on Net Operating Assets } \\
\hline & \multicolumn{2}{|c|}{ Mean } & t. Dev. & $\begin{array}{r}25^{\text {th }} \\
\text { ercentile }\end{array}$ & Median & $\begin{array}{r}75^{\text {th }} \\
\text { Percentile }\end{array}$ \\
\hline$\overline{\text { All Firms }(72,180 \text { obs. })}$ & \multicolumn{2}{|c|}{0.964} & 8.258 & 0.414 & 0.597 & 0.771 \\
\hline$(54,419$ obs. $)$ & \multicolumn{2}{|c|}{0.765} & 8.449 & & 0 . & 0.779 \\
\hline Loss Firms $(17,761$ obs. $)$ & \multicolumn{2}{|c|}{1.577} & 8.061 & 0.331 & 0.537 & 0.736 \\
\hline \multirow{2}{*}{\multicolumn{7}{|c|}{ 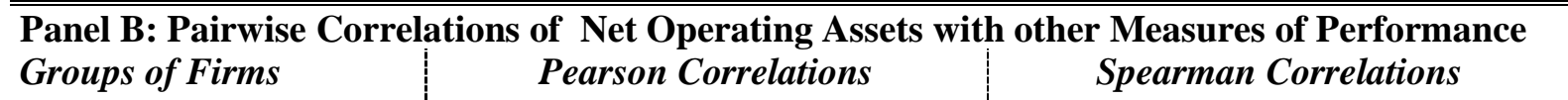 }} \\
\hline & & & & & & \\
\hline Groups of Firms & \multicolumn{2}{|c|}{$\Delta R O A_{t+1} \quad R E T_{t+1}$} & $A R E T_{t+1}$ & $\Delta R O A_{t+1}$ & $R E T_{t+1}$ & $A R E T_{t+1}$ \\
\hline$\overline{\text { All Firms }(72,180 \text { obs. })}$ & $-0.079 * * *$ & $-0.025 * *$ & $-0.022 * *$ & -0.118 & $-0.063 * * *$ & $-0.022 * * *$ \\
\hline Profit Firms $(54,419$ obs. $)$ & $-0.054 * * *$ & $-0.012^{*}$ & -0.008 & $-0.093 *$ & $-0.058 * * *$ & $-0.024 * * *$ \\
\hline Loss Firms (17,761 obs.) & $-0.117 * * *$ & $-0.048 * * *$ & $-0.045^{* * *}$ & $-0.159 * * *$ & $-0.102 * * *$ & $-0.037 * * *$ \\
\hline
\end{tabular}
Notes:

Net operating assets $\left(N O A_{t}\right)$ are equal to the difference between non cash assets (WO2999-W02001)and non-debt liabilities (W02999 - W03426 - W03255 - W03995), scaled by lagged total assets (WO2999). $\triangle R O A_{t+1}$ : is the one-year ahead profitability growth and equals to the change between one-year ahead profitability $\left(R O A_{t+1}\right)$ and current profitability $\left(R O A_{t}\right)$. Profitability is equal to net income (W01551) scaled by average total assets (WO2999).

$R E T_{t+1}$ is the one-year ahead raw return and equals to the compounded 12-month buy-hold return inclusive of dividends (using the return index provided by Datastream item RI).

$A R E T_{t+1}$ is the one-year ahead abnormal return and is calculated for any individual stock by subtracting the equal-weighted return of a benchmark portfolio matched by size (W08001) and book-to-market ratio (W03501/W08001) from the one-year ahead raw return of the stock.

" $W$ " denotes that the relevant data item comes from Worldscope.

Table 2. The NOA anomaly in European equity markets. This table reports time-series average values of net operating assets, profitability growth, raw and abnormal returns across portfolios formed on net operating assets for all firms included in the sample. Each year firms are sorted independently on net operating assets and allocated into five equal-sized portfolios (quintiles) based on these ranks. Spread is the difference in net operating assets, profitability growth, raw and abnormal returns (i.e., hedge return) between the highest (lowest) portfolios. The sample consists of 72,180 annual firm-year observations over the period $1989-2013 . * * * * *$, and $*$ denote statistical significance at $1 \%, 5 \%$, and $10 \%$ level, respectively, two-tailed.

\begin{tabular}{l|rrrrrr}
\hline Variables & Low & $\mathbf{2}$ & NOA Portfolios & High & Spread (H-L) \\
\hline$N O A_{t}$ & $19.66 \% * * *$ & $46.12 \% * * *$ & $60.06 \% * * *$ & $73.06 \% * * *$ & $113.61 \% * * *$ & $-93.95 \% * * *$ \\
$\Delta R O A_{t+1}$ & $1.39 \% * * *$ & $-0.16 \%$ & $-0.67 \% *$ & $-1.36 \% * * *$ & $-2.86 \% * * *$ & $4.25 \% * * *$ \\
$R E T_{t+1}$ & $15.68 \% * * *$ & $12.53 \% * *$ & $12.37 \% * *$ & $11.28 \% * *$ & $6.70 \%$ & $8.98 \% * * *$ \\
$A R E T_{t+1}$ & $2.30 \% * *$ & $1.40 \% * *$ & $1.32 \% *$ & $0.61 \%$ & $-3.24 \% * * *$ & $5.54 \% * * *$ \\
\hline \hline
\end{tabular}

As show in Table 2, by construction NOA increases monotonically from the bottom to the top NOA portfolio. We also observe that low NOA firms clearly outperform high NOA firms. 
In particular, low (high) NOA firms experience an increase (decrease) in one-year ahead profitability, while the resulted spread in the accounting rate of return between the bottom and the top portfolio is equal to $4.25 \%$. Additionally, low (high) NOA stocks earn high (low) raw returns and positive (negative) abnormal returns in the year following portfolio formation. The hedge (i.e., low less high) raw and abnormal returns are both highly statistically significant $(\mathrm{p}<0.001)$. The hedge raw return equates to $8.98 \%$ per annum, while the abnormal return equates to $5.54 \%$ per annum. Figure 1 plots the one-year ahead raw returns from the NOA hedge trading strategy broken down by year. The strategy is consistently profitable during the sample period (22 out of 25 years).

In Table 3 and 4 we present characteristics and returns to NOA portfolios for profit and loss firms, respectively. The dispersion of NOA across NOA quintiles is found widest for loss firms. Notably, profit firms within both the lowest and the highest NOA portfolio experience a negative change in future earnings performance. In contrary, within loss firms, low (high) NOA firms experience a positive (negative) change in one-year ahead accounting rate of return. The hedge portfolio has a positive growth in one-year ahead profitability of about $10.26 \%$ across loss firms, while the respective growth across profit firms declines to $1.12 \%$.

Table 3. The NOA anomaly for Profit Firms in European equity markets. This table reports time-series average values of net operating assets, profitability growth, raw and abnormal returns across portfolios formed on net operating assets for profit firms included in the sample. Each year firms are sorted independently on net operating assets and allocated into five equal-sized portfolios (quintiles) based on these ranks. Spread is the difference in net operating assets, profitability growth, raw and abnormal returns (i.e., hedge return) between the highest (lowest) portfolios. The sample of profit firms consists of 54,419 annual firm-year observations over the period $1989-2013$. ***,**, and * denote statistical significance at $1 \%, 5 \%$, and $10 \%$ level, respectively, two-tailed.

\begin{tabular}{|c|c|c|c|c|c|c|}
\hline \multirow[t]{2}{*}{ Variables } & \multicolumn{6}{|c|}{ NOA Portfolios } \\
\hline & Low & 2 & 3 & 4 & High & Spread (H-L) \\
\hline$N O A_{t}$ & $22.89 \% * * *$ & $48.49 \% * * *$ & $61.68 \% * * *$ & $73.99 \% * * *$ & $107.56 \%$ *** & $-84.68 \% * * *$ \\
\hline$\Delta R O A_{t+1}$ & $-2.18 \% * * *$ & $-1.78 \% * * *$ & $-1.53 \% * * *$ & $-1.76 \% * * *$ & $-3.30 \% * * *$ & $1.12 \% * * *$ \\
\hline$R E T_{t+1}$ & $15.67 \% * * *$ & $13.41 \% * * *$ & $12.87 \% * * *$ & $11.85 \% * *$ & $9.14 \% *$ & $6.53 \% * * *$ \\
\hline$A R E T_{t+1}$ & $1.77 \%$ ** & $1.61 \% *$ & $1.15 \%$ & $0.53 \%$ & $-1.66 \% * *$ & $3.43 \% * * *$ \\
\hline
\end{tabular}

Table 4. The NOA anomaly for Loss Firms in European equity markets. This table reports time-series average values of net operating assets, profitability growth, raw and abnormal returns across portfolios formed on net operating assets for loss firms included in the sample. Each year firms are sorted independently on net operating assets and allocated into five equal-sized portfolios (quintiles) based on these ranks. Spread is the difference in net operating assets, profitability growth, raw and abnormal returns (i.e., hedge return) between the highest (lowest) portfolios. The sample of loss firms consists of 17,761 annual firm-year observations over the period $1989-2013$. ***,**, and * denote statistical significance at $1 \%, 5 \%$, and $10 \%$ level, respectively, two-tailed.

\begin{tabular}{|c|c|c|c|c|c|c|}
\hline \multirow{2}{*}{ Variables } & \multicolumn{6}{|c|}{ NOA Portfolios } \\
\hline & Low & 2 & 3 & 4 & High & Spread (H-L) \\
\hline$N O A_{t}$ & $13.11 \% * * *$ & $39.60 \% * * *$ & $54.75 \% * * *$ & $69.43 \% * * *$ & $144.06 \% * * *$ & $-130.95 \% * * *$ \\
\hline$\Delta R O A_{t+1}$ & $8.80 \% * * *$ & $6.43 \% * * *$ & $3.06 \% * * *$ & $0.65 \%$ & $-1.46 \% *$ & $10.26 \%$ *** \\
\hline$R E T_{t+1}$ & $16.42 \% * *$ & $12.88 \% * *$ & $8.59 \%$ & $9.04 \%$ & $-0.52 \%$ & $16.94 \% * * *$ \\
\hline$A R E T_{t+1}$ & $4.33 \% * *$ & $2.71 \% *$ & $0.77 \%$ & $1.23 \%$ & $-6.95 \% * * *$ & $11.28 \% * * *$ \\
\hline
\end{tabular}


Figure 1. Raw returns based on NOA hedge trading strategy for All Firms.

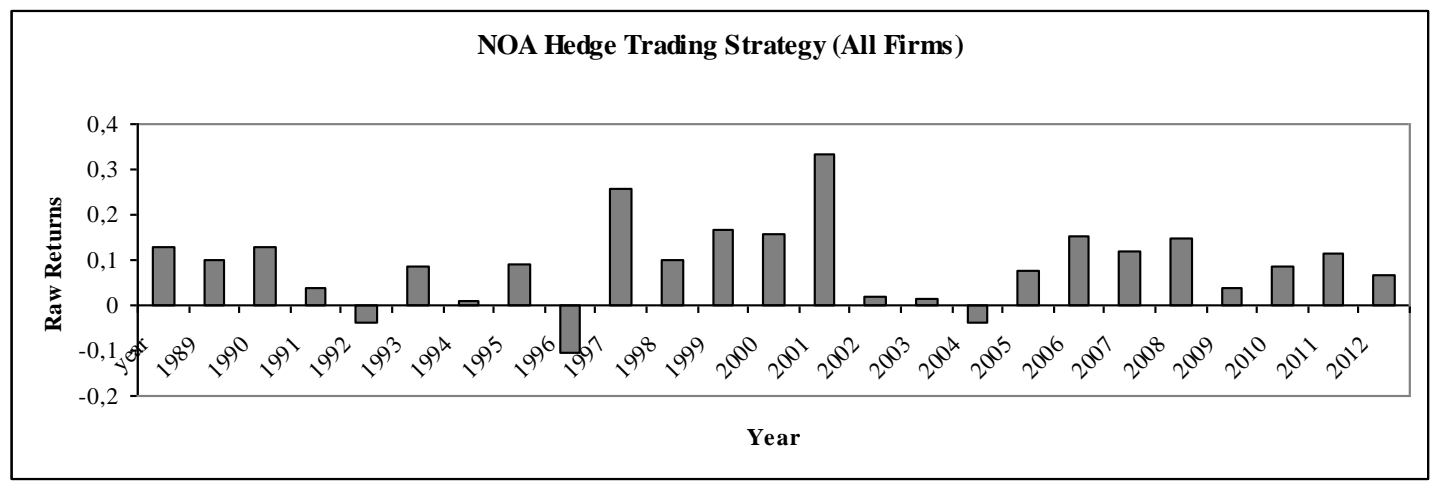

Figure 2. Raw returns based on NOA hedge trading strategy for Profit Firms.

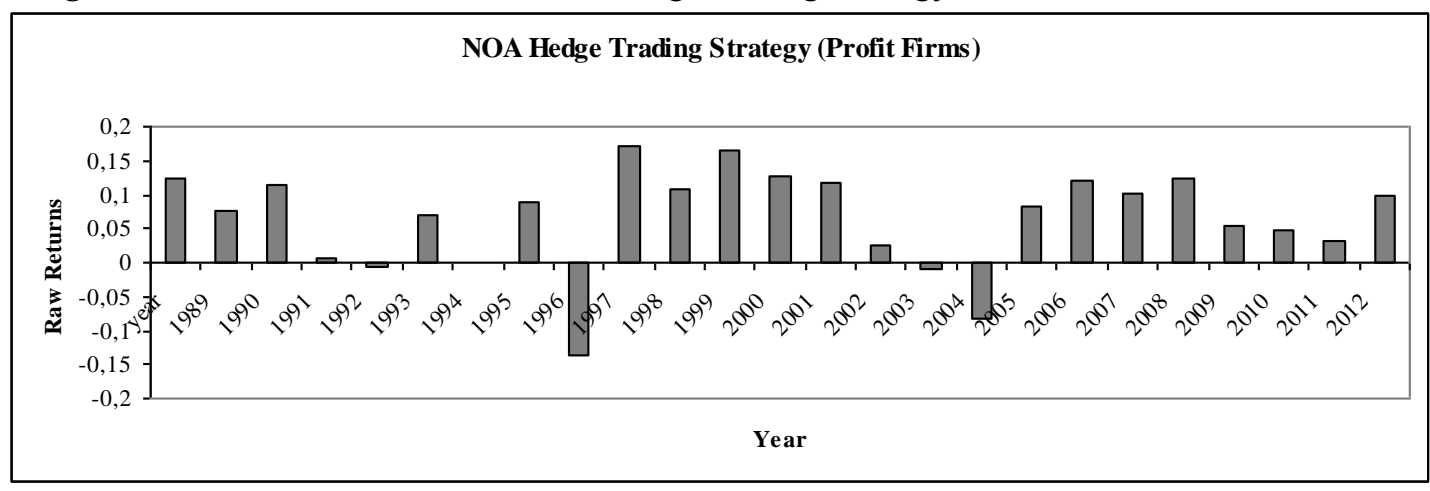

Figure 3. Raw returns based on NOA hedge trading strategy for Loss Firms.

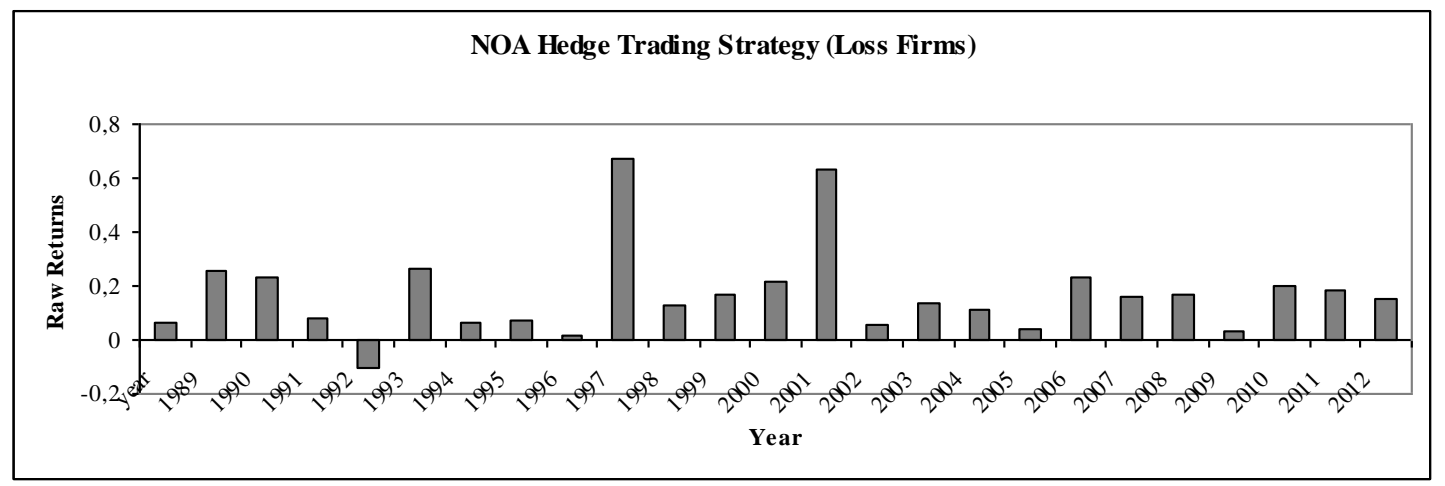

Within the profit subsample, raw returns decrease from $15.67 \%$ for the bottom NOA quintile to $9.14 \%$ for the top NOA quintile, yielding a spread in returns between extreme portfolios of $6.53 \%$. Within the loss subsample, average raw returns decline from $16.42 \%$ for low NOA firms to $-0.52 \%$ for high NOA firms, yielding a hedge return of $16.94 \%$. The abnormal return on trading strategy of buying/selling firms with low (high) NOA is equal to $3.43 \%$ and $11.28 \%$ for profit and loss firms, respectively.

Figures 2 and 3, graph the equally-weighted raw returns from the NOA hedge trading strategy year by year, for profit and loss firms, respectively. As shown, the strategy is profitable in 21 out of 25 years under investigation for profit firms, and 24 out of 25 years under investigation for loss firms. The difference in hedge raw and abnormal returns between profit and loss firms is economically large and highly statistical significant. In particular, the difference in hedge raw returns between profit and loss firms is equal to $10.49 \%(\mathrm{t}$-statistic $=3.305)$, while the respective difference in abnormal returns is equal to $7.85 \%$ (t-statistic $=2.878$ ).

Finally, we provide insights from cross-sectional regressions about the NOA effect on future 
returns, conditional of the sign of accounting earnings. We estimate cross-sectional regressions of one-year ahead raw returns on net operating assets, conditional on size and book to market ratio, using an indicator variable to capture losses. We estimate regressions with the Fama and McBeth (1973) procedure and report the time-series averages of the resulted parameter coefficients. All independent variables enter the regressions are winsorized at the top and bottom $1 \%$ of their own distribution to avoid the effects of possible outliers. When estimating regressions, we use the entire sample of stocks, and then split into a subsample of big stocks and a subsample of small and micro stocks. In doing so, we attempt to assess the pervasiveness of the NOA effect on stock returns, conditional on profits and losses, across different size groupings. Following Fama and French (2012), the breakpoints should be chosen that big stocks represent the top $90 \%$ of the aggregated market capitalization six months after financial year-end (7,102 firmyear observations) and, small and micro stocks represent the bottom $10 \%$ of the aggregated market capitalization six months after financial year-end (65,078 firm year observations).

Our regression model takes the following form:

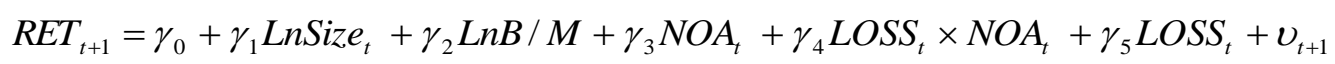

Table 5. Cross-sectional regressions. This table reports results from cross-sectional regressions of oneyear raw returns on net operating assets, using a dummy variable for losses (i.e., LOSS) that takes the value of one, when current earnings are negative, and the value of zero otherwise. We also include in the regressions the natural logarithm of size (i.e., market capitalization) and the natural logarithm of book to market ratio as standard asset pricing controls. We estimate annual cross-sectional regressions and report the time-series averages of the parameter coefficients. In doing so, we use the entire sample of stocks and a subsample of big stocks and, small and micro stocks. The entire sample consists of 72,180 annual firm-year observations over the period 1989 - 2013. The subsample of big stocks consists of those that comprise the top $90 \%$ of the aggregated market capitalization six months after financial year-end (7,102 firm-year observations). The subsample of small and micro stocks consists of those that comprise the bottom $10 \%$ of the aggregated market capitalisation six months after financial year-end (65,078 firm year observations). Panel A, B and C reports results for all stocks, big stocks and, small and micro stocks, respectively. $* * *, * *, *$ represents statistical significance of coefficients at $1 \%, 5 \%$, and $10 \%$ level, respectively, two-tailed.

\begin{tabular}{|c|c|c|c|c|c|c|}
\hline Panel A: Reg & ions of & re Raw Re & $\begin{array}{l}\text { us on NOA } \\
M+\gamma N O\end{array}$ & $\begin{array}{l}\text { Il Stocks) } \\
+\gamma(O S\end{array}$ & $A$ & $+1)$ \\
\hline$\gamma_{0}$ & $\gamma_{1}$ & $\gamma_{2}$ & $\gamma_{3}$ & $\gamma_{4}$ & $\gamma_{5}$ & $\operatorname{Adj} R^{2}$ \\
\hline $0.154 * * *$ & 0.001 & $0.042 * * *$ & $-0.072 * * *$ & $-0.073 * * *$ & $-0.036 * *$ & 0.036 \\
\hline
\end{tabular}

Panel B: Regressions of Future Raw Returns on NOA (Big Stocks)

\begin{tabular}{ccccccc} 
Model: RET $_{t+1}=$ & $\gamma_{0}+\gamma_{1}$ LnSize $_{t}+\gamma_{2} L n B / M+\gamma_{3} N O A_{t}+\gamma_{4} L O S S_{t} \times N O A_{t}+\gamma_{5} L_{\text {LSS }}+v_{t+1}$ \\
\hline$\gamma_{0}$ & $\gamma_{1}$ & $\gamma_{2}$ & $\gamma_{3}$ & $\gamma_{4}$ & $\gamma_{5}$ & $A d j R^{2}$ \\
$0.681^{* * *}$ & $-0.033^{* * *}$ & 0.021 & -0.028 & 0.013 & -0.048 & 0.058 \\
\hline
\end{tabular}

Panel C: Regressions of Future Raw Returns on NOA (Small and Micro Stocks)

\begin{tabular}{ccccccc} 
Model: RET $_{t+1}=$ & $\gamma_{0}+\gamma_{1}$ LnSize $_{t}+\gamma_{2}$ LnB $/ M+\gamma_{3} N O A_{t}+\gamma_{4}$ LOSS $_{t} \times N O A_{t}+\gamma_{5}$ LOSS $_{t}+v_{t+1}$ \\
\hline$\gamma_{0}$ & $\gamma_{1}$ & $\gamma_{2}$ & $\gamma_{3}$ & $\gamma_{4}$ & $\gamma_{5}$ & Adj R $R^{2}$ \\
$0.234 * * *$ & -0.006 & $0.042 * * *$ & $-0.074 * * *$ & $-0.074 * * *$ & $-0.041^{* *}$ & 0.037 \\
\hline \hline
\end{tabular}

In the above models, LOSS is a dummy variable taking the value 1, if current earnings are less than zero at financial year-end, and 0 otherwise. Based on the specification of each of the above models, $\gamma_{3}$ captures the effect of net operating assets on one-year ahead raw returns for profit firms, while $\gamma_{4}$ captures the respective incremental effect for loss firms. 
Results from cross-sectional regressions are reported in Table 5. Panel A, B and C reports results for all stocks, big stocks and, small and micro stocks, respectively. Regarding the entire sample of stocks, there is a negative effect of net operating assets on future stock returns within profit firms $\left(\gamma_{3}=-0.072\right)$ At the same time, the effect of the operating assets on future stock returns is found to be more severe within loss firms $\left(\gamma_{4}=-0.073\right)$. As shown in Panel $\mathrm{C}$, the above results are more likely to be driven by small and micro stocks. In particular, for profit firms the coefficient $\gamma_{3}$ is equal to -0.074 , while for loss firms the incremental coefficient $\gamma_{4}$ is equal to -0.074 . Regarding big stocks, it seems that the NOA anomaly is strongly attenuated and becomes statistically insignificant for both profit and loss firms.

\section{Conclusion}

The results in this study indicate that in developed European capital markets, the NOA anomaly is highly significant and stronger across loss firms, but it is dampened across profit firms. These results are consistent with the hypothesis that low NOA firms may have superior returns relative to high NOA firms due to investors' inability to make full use of information reported in financial statements (Hirshleifer et al. 2004).3 At the same time, our evidence of higher returns to a hedge trading strategy based on NOA, when excluding profit firms, may be valuable for fund managers in the process of making a reliable global stock selection.

\section{Acknowledgements}

The paper has benefited from insightful comments and suggestions from Gikas Hardouvelis, Dimitrios Thomakos and two anonymous reviewers. The usual disclaimer applies..

\section{References}

Basu, S. (1997) The conservatism principle and the asymmetric timeliness of earnings, Journal of Accounting and Economics, 24, 3-37.

Chan, L., Dimmock, S. and Lakonishok, J. (2009) Benchmarking Money Manager Performance: Issues and Evidence, Review of Financial Studies, 22, 4553-4599.

Fama, E. and MacBeth, J. (1973) Risk, return, and equilibrium: empirical tests, Journal of Political Economy, 81, 607-636.

Fama, E. and French, K. (1993) Common risk factors in the returns on stocks and bonds, Journal of Financial Economics, 33, 3-56.

Fama, E. and French, K. (2008) Dissecting anomalies, Journal of Finance, 63, 1653-1678.

Fama, E. and French, K. (2012) Size, value, and momentum in international stock returns, Journal of Financial Economics, 105, 457-472.

Fama, E. and French, K. (2015) A five-factor asset pricing model, Journal of Financial Economics, 116, 1-22.

Fama, E. and French, K. (2017) International tests of a five-factor asset pricing model, Journal of Financial Economics, 123, 441-463.

Grobys, K. (2014) Momentum in global equity markets in times of troubles: Does the economic state matter?, Economic Letters, 123, 100-103.

Ince, O. and Porter, R. B. (2006) Individual equity return data from Thomson Datastream: Handle with care, Journal of Financial Research, 29, 463-479.

\footnotetext{
${ }^{3}$ Our empirical findings could be also partially consistent with the profitability part of q-theory, which suggests that firms with low profitability (or high probability of losses) will have lower expected returns relative to firms with high profitability (see Hou et al. 2015).
} 
Hayn, C. (1995) The information content of losses, Journal of Accounting and Economics, 20, $125-153$.

Hou, K., Xue, C. and Zhang, L. (2015) Digesting anomalies: An investment approach, Review of Financial Studies, 28, 650-705.

Hirshleifer, D., Hou, K., Teoh, S. and Zhang Y. (2004) Do investors overvalue firms with bloated balance sheets?, Journal of Accounting and Economics, 38, 297-331.

Hirshleifer, D., Hou, K. and Teoh, S. (2012) The accrual anomaly: Risk or mispricing?, Management Science, 58, 320-335.

Papanastasopoulos, G. and Thomakos, D. (2017) Managerial discretion, net operating assets and the cross-section of stock returns: Evidence from European countries, Journal of International Financial Markets, Institutions and Money, 47, 188-210.

Patatoukas, P. (2016) Asymmetrically timely loss recognition and the accrual anomaly, Abacus, 52, 166-175.

Pinnuck, M. and Shekhar. C. (2013) The Profit versus Loss Heuristic and Firm Financing Decisions, Accounting, Organizations and Society, 38, 420-439.

Schleicher, T., Hussainey, K. and Walker, M. (2007) Loss firms' annual report narratives and share price anticipation of earnings, The British Accounting Review, 39, 153-171.

Wu. J., Zhang, L. and Zhang, F. (2010) The q-theory approach to understanding the accrual anomaly, Journal of Accounting Research, 48, 177-223. 